Selcuk Journal of Agriculture and Food Sciences

http://sjafs.selcuk.edu.tr/sjafs/index

Research Article

\section{SJAFS}

(2020) 34 (1), 1-6

e-ISSN: $2458-8377$

DOI:10.15316/SJAFS.2020.187

\title{
Adaptation of Some Blackberry Varieties in Konya Ecological Conditions
}

\author{
Fadime ALTUNBAŞ ${ }^{1}$, Lütfi PIRLAK ${ }^{2 *}$ \\ ${ }^{1}$ Alp Tarım İlaçları Paz. San. Tic. Ltd. Şti., Konya, Turkey \\ ${ }^{2}$ Selçuk University, Faculty of Agriculture, Department of Horticulture, Konya, Turkey
}

\begin{tabular}{l}
\hline ARTICLE INFO \\
\hline Article history: \\
Received date: 10.09 .2019 \\
Accepted date: 27.11.2019 \\
\hline Edited by: \\
Ali SABIR; Selçuk University, Turkey \\
Reviewed by: \\
Aydın UZUN; Erciyes University, \\
Turkey \\
Ahmet EŞiTKEN; Selçuk University, \\
Turkey \\
\hline Keywords: \\
Blackberry \\
Adaptation \\
Phonology \\
Morphology \\
Pomology \\
Konya
\end{tabular}

\section{Introduction}

Blackberry is located in the genus Eubatus of the genus Rubus of the Rosaceae family. This view of blackberries, which are included in the list of plants that should be destroyed in agricultural areas, continued until the second half of the 19th century. Many varieties have been developed with the discovery of hybrid blackberries in wild form by researchers and the cultivation and cultivation studies in America in the 1850s (Poling, 1997). Blackberry breeding work first began in the US state of Texas about 150 years ago (Moore, 1984).

Research on the cultural forms of blackberries began in the mid-18th century, and in 1931 Darrow reformed Thornless Evegreen, the first thornless blackberry variety (Hall et al., 1986).

Turkey's climate, a great product with very few countries around the world has created growing potential and diversity (Agaoglu et al., 2006). Turkey is located within the natural spreading areas of grape fruits. These species are both highly sought after by consumers and have a wide range of uses. These species are easily

\footnotetext{
* Corresponding author email: pirlak@selcuk.edu.tr
}

propagating, early fruit lying, also used as hedge plants, orchards in the garden can be evaluated as plants. Since these fruits are consumed in large amounts in high income countries, they have a large market in the world. Wild forms of this kind in Turkey for many years consumption the cultural forms in recent years have also begun to be recognized. Raspberries and currants can be grown on the north-facing slopes of the North Anatolian Mountains and at altitudes higher than $1000 \mathrm{~m}$ and blackberries can be grown naturally in almost all regions. Central Anatolia and Black Sea regions, especially Çorum, Amasya, Yozgat, Gümüşhane and Rize provinces are at the beginning of these areas (Onur, 2006).

In recent years, studies have shown that blackberries are very important for human health and contain anticarcinogenic and antioxidant chemicals. These plants have 4-6 grams of fiber per 100 grams and although they contain small amounts of vitamins A, B, C have been reported to be effective against heart disease and colon cancer. Ellagic acid, which is highly anticarcinogenic in all of these species, has been shown to prevent tumor development in animal studies under laboratory conditions. The colors, taste and aromas, structures and odors of blackberries are attractive. Therefore, it is used in the production of fruit juice, ice 
cream, jam, marmalade as well as fresh consumption (Pehluvan and Güleryüz, 2004).

Blackberry with an economic life of 15-20 years is not very selective in terms of climate requirements and can easily adapt to different climatic conditions. Abundant sun, protected from winds, rain at harvest time, soil moisture is sufficient and can be easily grown in places where the winters are warm (Barut, 2004).

In recent years, there has been an increasing interest in blackberry cultivation in Turkey due to its richness in vitamins, minerals and antioxidant capacity, highlighting its benefits in terms of human health and increasing the usage areas in industry. In the Black Sea and Marmara Regions, commercial orchard gardens have been established. But there is no production yet to record. Increasing the production and trade of blackberries will help to develop different areas of industry on blackberry as well as to solve problems such as unemployment and migration (Kaplan et al., 1999).

As a result of breeding studies on blackberries, high yields were obtained as a result of the development of large fruit varieties and application of new finishing systems. This situation especially increased the interest of small farmers to this fruit (Çetiner et al., 1993).

In the agricultural statistics of Turkey, blackberry production first took place as 1319 tons in 1995 and after that year, production increased slowly, it increased to 1800 tons in 2000, 2200 tons in 2005, and 4989 tons in 2010 (TUİK, 2019).

In recent years, there has been an increasing interest in blackberry growing in Konya. However, the lack of a scientific study on the varieties that can be grown in the province in a large number of blackberries is an important deficiency. This study was carried out in order to determine the growth characteristics and adaptability of different blackberry varieties in Konya ecological conditions.

\section{Materials and Methods}

\subsection{Materials}

The study was conducted in 2017-2018 in the district of Büyükkovanağzı in Meram district of Konya. Arphe, Boata, Chester and Jumbo blackberries were used as plant material. Phenological, morphological, pomological and chemical properties and yields of plants were investigated during the study. Plant materials were obtained from a special nursery plant in tubular form.

\subsection{Methods}

The research was conducted between 2017-2018 in open land conditions. The study area was prepared in October 2016. Plants were planted again in October and 'double $\mathrm{T}$ ' training system and drip irrigation system were applied.

Blackberry plants were planted with 3 replications with 10 plant in each repetition and $1 \mathrm{~m}$ above the row and $2 \mathrm{~m}$ between the rows. In both years, fruit samples taken during harvest period were brought to the laboratory and examined. Since the study area was established in autumn 2016, the plants did not yield fruit in 2017.

Phenological observations in plants due to Islam et al. (2009) according to the swelling date of vegetative buds, the date of waking up of vegetative buds, vegetative buds of the date of the first shoot, the date of the release of the flower table, the date of the beginning of flowering, full flowering date, the last flowering date, the first fruit formation date, the first harvest date, the last harvest date.

The number of canes per plant, cane height, cane diameter, number of clusters in cane, number of fruit in clusters and cane yield for Islam et al. (2009).

Fruit width and length $(\mathrm{mm})$ and fruit weight were determined in 25 fruits taken randomly.

Fruit color $(\mathrm{L} *$. A *. B*) was measured with $\mathrm{Mi}$ nolta color meter. $\mathrm{L}$ is the brightness value, 0 is black and 100 is white. "A" shows redness (-a green) and b yellowness (-b blue) (McGuire, 1992).

The taste and aroma status of the varieties were evaluated according to the 1-5 scoring system by taking the average of the taste and aroma analysis evaluations made to 5 people. (1: very bad, 2: bad, 3: moderate, 4: good, 5: very good).

Fruit shape (spherical, long conical, short conical, conical) was determined by visual evaluation of 25 fruits taken randomly in determining fruit shape.

Amount of total soluble solids (\%) was determined by digital hand refractometer, fruit juice $\mathrm{pH}$ was determined by $\mathrm{pH}$ meter, the amount of titratable acid (\%) was determined by titration method and vitamin C was determined by spectrophotometric dichlorophenol indophenol method (mg / 100g) (Pearson, 1976).

The experiment was set up in a randomized plot design with three replications. The data obtained were analyzed using JMP (version 7.0 SAS Instute, Cary, NC, USA).

\section{Results and Discussion}

\subsection{Phenological observations}

The results of the 2017-2018 phenological observations for the four blackberry varieties used in our research are given in Tables 1 and 2. Variety of vegetative buds swelling in 2017 were in 24 February (Boata), 28 February Arphe, 29 February (Chester) and 3 March (Jumbo), in 2018 were in 26 February (Boata), 1 March (Arphe), 3 March (Chester), 5 March (Jumbo). Akbulut et al. (2003), in their study in Samsun conditions reported that the vegetative buds of the blackberry varieties swell between the second week and the third week of March. Kurt et al. (2003), in the study conducted in Giresun, it was determined that the swelling date of vegetative buds is between 24 February and 2 April. 
The awakening date of the vegetative buds in 2017 takes place on 29 February (Boata), 6 March (Chester), 7 March (Arphe), 3 March (Chester); in 2018 was held on March 3 (Boata), March 9 (Chester), March 10 (Arphe), March 12 (Jumbo). In an adaptation study conducted in Isparta, vegetative buds awakened between April 3-21 (Göktaş et al., 2006).

In 2017, vegetative buds continued on March 5 (Boata), March 10 (Chester), March 12 (Arphe) and March 14 (Jumbo). In 2018, it took place on 10 March (Boata), 15 March (Chester), 16 March (Arphe) and 17 March (Jumbo). Agaoglu et al. (2003), in Ankara Ayaş conditions in the study conducted on April 1 vegetative buds of Chester variety was determined.

The first exits were in March 2017 (Jumbo), April 2 (Arphe), April 6 (Boata), April 7 (Chester); In 2018, it was held on 5 April (Jumbo), 8 April (Arphe), 19 April (Chester) and 14 April (Boata).

The date of the first flowering in 2018 is 13 May (Jumbo), 15 May (Chester), 27 May (Arphe), 8 June (Boata); The first flowering took place on May 20 (Jumbo), May 23 (Chester), June 3 (Arphe), June 15 (Boata). Full flowering periods June 3 (Jumbo), June 5 (Chester), June 15 (Arphe), June 20 (Boata); the last flowering occurred on July 13 (Boata), July 20 (Arphe), September 3 (Jumbo), September 10 (Chester). Kurt et al. (2003), Giresun in the study of flower clusters were determined to be between 19 March and 10 May. In the study of Göktaş et al. (2006), in Isparta in the study of the cluster of flowering dates were determined between 11-28 May. In the study conducted by Cangi and İslam (2003) in Ordu, it was determined that the first flowering occurred between 2 May and 7 June. In the study conducted in Giresun, the first flowering took place between 4 April and 5 June (Kurt et al., 2003). Akbulut et al. (2003), by the full bloom period of the blackberries in Samsun Çarşamba region was determined to be between the first week of May and the second week of July. In the study of Göktaş et al. (2006), some blackberry varieties in the first flowering period in Isparta conditions between June 3 to July 12 have determined that.

In 2018, the first fruit formation took place on 1 July (Jumbo), 3 July (Chester), 12 July (Boata) and 20 July (Arphe). In the study of Göktaş et al. (2006), in the study conducted in Isparta in the first fruit formation dates were determined between June 5-30. Agaoglu et al. (2003), in the study conducted in the region of Ankara by the date of the first fruit formation was found between 4-19 July.

The first fruit harvest dates for 2018 are 5 July (Jumbo and Chester), 15 July (Boata), 22 July (Arphe) and the last harvest dates are 26 July (Boata), 17 August (Arphe), 10 September (Jumbo), 16 September (Chester). In addition, since September 16, new fruit has been formed in Chester variety but could not be harvested because it is not ripe. In the study conducted in Ayaş district of Ankara, the first harvest dates of blackberry varieties were determined between 11-22
July and the last harvest dates were between 16-22 August (Ağaoğlu et al., 2003).

Defoliation dates for 2017 are 10 November (Jumbo), 12 November (Chester), 16 November (Boata), 20 November (Arphe); In 2018, it was determined as 12 November (Jumbo), 15 November (Chester), 20 November (Boata) and 25 November (Arphe). It is important that blackberry varieties enter early to rest in cold winters in order to avoid winter damage of annual shoots. In the cultivars cultivated under Konya conditions, no damage was detected during winter shoots during the annual shoots. Agaoglu et al. (2003), the study conducted by Ankara conditions in the blackberry variety was determined to occur between 7-25 December defoliation.

\subsection{Plant characteristics}

Some cane characteristics of cultivars in 2017-2018 are given in Tables 3 and 4. Accordingly, the differences between the varieties were found to be statistically significant in terms of all the characteristics examined. When the exile numbers of the varieties were examined in 2017; Arphe was the first with 4.03 cane, followed by Jumbo (2.5), Chester (2.43) and Boata (1.96). In 2018, Arphe had the highest number of cane with 6.53. This was followed by Jumbo (4.53 units), Chester (3.80 units) and Boata (2.53 units). Kurt et al. (2003) in the study conducted in the region of Giresun Chester variety of 6 , Jumbo was found to give 2 cane.

In 2017, the maximum cane length was Arphe with $260.26 \mathrm{~cm}$, followed by Jumbo with $225.03 \mathrm{~cm}$. In 2018, Arphe $(350.8 \mathrm{~cm})$ had the highest cane length, followed by Jumbo $(260.56 \mathrm{~cm})$, Chester $(247.73 \mathrm{~cm})$ and Boata $(147.96 \mathrm{~cm})$, respectively (Table 4.). Esmek et al. (2011) in a study conducted in the region of Erzincan cane length of $275.90 \mathrm{~cm}$ in Jumbo variety, $272.36 \mathrm{~cm}$ was found in Chester.

In 2017, the difference between cane varieties was found to be statistically significant, with Chester (2.96 $\mathrm{mm})$ in the first place, followed by Jumbo $(2.52 \mathrm{~mm})$, Arphe $(2.42 \mathrm{~mm})$ and Boata $(2.31 \mathrm{~mm})$ (Table 3). In 2018, cane diameter was between $3.25 \mathrm{~mm}$ (Boata) and $4.26 \mathrm{~mm}$ (Chester).

When the number of clusters per cane is examined, Chester ranks first with 0.60 , while Jumbo variety ranks second with 0.43 . In a study conducted in Ordu region, the number of clusters per cane was found as 2 in Jumbo cultivar (Cangi and İslam, 2003).

According to fruit number per cluster, Jumbo with 13.63 and Chester with 13.33 had the highest fruit, followed by Chester with 9.76 and Boata with 3.33. In a study conducted in Ordu, the number of fruit paer clusters was 8.96 in Chester and 5.50 in Jumbo (Cangi and Islam, 2003).

When the yield per cane was examined, Jumbo ranked first with $14.07 \mathrm{~g}$, followed by Chester with $9.1 \mathrm{~g}$, Arphe with $1.75 \mathrm{~g}$ and Boata with $1.01 \mathrm{~g}$.

\subsection{Pomological features}


The results of the fruit colors of the varieties are given in Table 5. The differences between the $\mathrm{L}$ and $\mathrm{H}$ values of the varieties were statistically insignificant and the difference between the $\mathrm{C}$ values was significant. The highest $\mathrm{C}$ value was found in Boata variety (11.53).

According to 2018 data, Arphe was the best variety with the best taste and aroma, while the other varieties took the same score and ranked second in terms of taste. Arphe, with the highest aroma score, was followed by Chester. Agaoglu et al. (2003), in Ankara, the highest scores in terms of taste and aroma Chester (5) and Jumbo (5) varieties. In the study conducted in Trabzon, Chester received 4 points and Jumbo 3 points in taste scoring (İslam et al., 2009).

As a result of the visual evaluation of 25 fruits taken randomly in terms of fruit shapes, it was determined that Jumbo varieties had long-conical, Chester varieties had short-conical, Arphe varieties had round and Boata varieties had short-conical fruits.

Fruit varieties with the least width $4.88 \mathrm{~mm}$ Boata, the highest variety with $17.47 \mathrm{~mm}$ was found as Chester. In a study conducted in Erzincan, fruit width was found to be $19.47 \mathrm{~mm}$ in Jumbo cultivar and $18.08 \mathrm{~mm}$ in Chester cultivar (Esmek et al., 2011).

The fruit length of blackberry varieties was between $5.07 \mathrm{~mm}$ (Boata) and $18.45 \mathrm{~mm}$ (Jumbo) and the differences between varieties were found to be statistically significant. Islam et al. (2009), in the study conducted by Trabzon in fruit Jumbo variety was found to be $21.00 \mathrm{~mm}$, while Chester was $20.09 \mathrm{~mm}$.

The differences between the varieties in terms of fruit weight were found to be statistically significant. The highest fruit weight was Jumbo (3.60 g), followed by Chester (2.81 g), Arphe (1.19 g) and Boata (0.72 g), respectively. In a study conducted by Cangi and İslam (2003) in Ordu, the fruit weight was found to be $4.1 \mathrm{~g}$ in Jumbo cultivar and $2.91 \mathrm{~g}$ in Chester. In a study conducted in Ankara Ayaş region, fruit weight was found to be $5.7 \mathrm{~g}$ in Chester variety and $4.13 \mathrm{~g}$ in Jumbo (Ağaoğlu et al., 2003). The differences between the results are related to the ecology of aquaculture sites.

\section{Chemical Properties}

The difference between the TSS values of the varieties was found to be statistically significant. Arphe $(17.13 \%)$, followed by Boata (16.53\%), Jumbo (16.03\%) and Chester (14.20\%), had the highest TSS.

Kurt et al. (2003) in the study conducted in Giresun TSS Chester $13.13 \%$ and $9.98 \%$ in Jumbo was determined. In the study conducted in Samsun Chester and Jumbo varieties TSS values were found to be $9.9 \%$ and $10.3 \%$, respectively (Akbulut et al., 2003). Similarly, ecological factors were also effective here. Under the conditions of Konya, TSS is higher than the blackberries grown in the Black Sea region, it is a result of high temperature, low relative humidity and high day and night temperature differences. In addition, an increase in altitude increases the accumulation of dry matter.
The differences between the $\mathrm{pH}$ values of the varieties were found to be statistically significant, while the highest $\mathrm{pH}$ value was Arphe (3.93), followed by Boata (3.90), Jumbo (3.71) and Chester (3.57), respectively. In the study conducted in Trabzon, $\mathrm{pH}$ was found to be 3.34 and 3.16 in Jumbo and Chester varieties, respectively (İslam et al., 2009). Gerçekçioğlu et al. (2003), in their study in Tokat Jumbo varieties have determined the $\mathrm{pH}$ as 3.15 .

The difference between the titratable acidity of the varieties was found to be statistically significant, in terms of acidity, Jumbo cultivar $(0.60 \%)$ was first, followed by Chester $(0.38 \%)$, Boata $(0.34 \%)$ and Arphe $(0.34 \%)$. In the study of Göktaş et al. (2006) in a study conducted in Isparta, titratable acid amounts were found to be $1.26 \%$ in Jumbo cultivar and $1.19 \%$ in Chester. In the study conducted in Trabzon, acidity value of Jumbo and Chester varieties was $1.38 \%$ and $1.27 \%$, respectively (İslam et al., 2009). The difference between the results is related to the ecology of production regions.

The differences between the varieties in terms of vitamin C content were found statistically insignificant. Vitamin $\mathrm{C}$ values in the varieties between $24.98 \mathrm{mg} /$ $100 \mathrm{~g}$ (Arphe) and $26.67 \mathrm{mg} / 100 \mathrm{~g}$.

\section{Conclusions}

According to the results of the study carried out on four blackberries in 2017-2018 in Meram district of Konya, Jumbo was in the first place with $14.07 \mathrm{~g}$ in yield per shoot, followed by Chester with $9.1 \mathrm{~g}$. In terms of fruit taste and aroma, Arphe came to the forefront, followed by Chester. Jumbo was in the first place when the cultivars were compared in terms of yield, followed by Chester. According to the research results, it can be said that Chester and Jumbo varieties are superior to other varieties and can be recommended for the region.

\section{Acknowledgement}

This research was prepared from the Master of Science Thesis (in Selcuk University) entitled "Bazı bögürtlen Çeşitlerinin Konya Ekolojik Şartlarına Adaptasyonu".

This research was supported by a grant from Center of Scientific Research Project of Selçuk University (Project Number: 17201095. 
Altuntaş and Pirlak / Selcuk J Agr Food Sci, (2020) 34 (1), 1-6

Table 1

Phenological data of blackberry varieties

\begin{tabular}{|c|c|c|c|c|c|c|c|}
\hline Varieties & Years & $\begin{array}{c}\text { Vegetative } \\
\text { buds swelling } \\
\text { date }\end{array}$ & $\begin{array}{l}\text { Awakening date of } \\
\text { the vegetative buds }\end{array}$ & $\begin{array}{c}\text { Vegetative } \\
\text { buds continued } \\
\text { date }\end{array}$ & $\begin{array}{c}\text { First shoot } \\
\text { date }\end{array}$ & $\begin{array}{c}\text { The first } \\
\text { flower for- } \\
\text { mation }\end{array}$ & $\begin{array}{l}\text { First flowe- } \\
\text { ring date }\end{array}$ \\
\hline \multirow{2}{*}{ Jumbo* } & 2017 & 03.03 & 10.03 & 14.03 & 29.03 & - & - \\
\hline & 2018 & 05.03 & 12.03 & 17.03 & 05.04 & 13.05 & 20.05 \\
\hline \multirow{2}{*}{ Chester* } & 2017 & 29.02 & 06.03 & 10.03 & 07.04 & - & - \\
\hline & 2018 & 03.03 & 09.03 & 15.03 & 10.04 & 15.05 & 23.05 \\
\hline \multirow{2}{*}{ Arphe* } & 2017 & 28.02 & 07.03 & 12.03 & 02.04 & - & - \\
\hline & 2018 & 01.03 & 10.03 & 16.03 & 08.04 & 27.05 & 03.06 \\
\hline \multirow{2}{*}{ Boata* } & 2017 & 24.02 & 29.02 & 05.03 & 06.04 & - & - \\
\hline & 2018 & 26.02 & 03.03 & 10.03 & 14.04 & 08.06 & 15.06 \\
\hline
\end{tabular}

* No flower in the first year

Table 2

Phenological data of blackberry varieties

\begin{tabular}{|c|c|c|c|c|c|c|c|}
\hline Varieties & Years & $\begin{array}{l}\text { Full flowe- } \\
\text { ring date }\end{array}$ & $\begin{array}{l}\text { Last flowe- } \\
\text { ring date }\end{array}$ & $\begin{array}{l}\text { First fruit forma- } \\
\text { tion date }\end{array}$ & $\begin{array}{l}\text { First har- } \\
\text { vest date }\end{array}$ & $\begin{array}{l}\text { Last har- } \\
\text { vest date }\end{array}$ & $\begin{array}{c}\text { Defoliation } \\
\text { date }\end{array}$ \\
\hline \multirow{2}{*}{ Jumbo* } & 2017 & - & - & - & - & - & 10.11 \\
\hline & 2018 & 03.06 & 02.09 & 01.07 & 05.07 & 10.09 & 12.11 \\
\hline \multirow{2}{*}{ Chester* } & 2017 & - & - & - & - & - & 12.11 \\
\hline & 2018 & 05.06 & 10.09 & 03.07 & 05.07 & 16.09 & 15.11 \\
\hline \multirow{2}{*}{ Arphe* } & 2017 & - & - & - & - & - & 20.11 \\
\hline & 2018 & 15.06 & 20.07 & 20.07 & 22.07 & 17.08 & 25.11 \\
\hline \multirow{2}{*}{ Boata* } & 2017 & - & - & - & - & - & 16.11 \\
\hline & 2018 & 20.06 & 13.07 & 12.07 & 15.07 & 26.07 & 20.11 \\
\hline
\end{tabular}

* No flower in the first year

Table 3

Plant characteristics of blackberry varieties (2017)

\begin{tabular}{cccc}
\hline Varieties & Cane number & Cane length & Cane diameter \\
\hline Jumbo & $2.50 \mathrm{~b}$ & $255.03 \mathrm{~b}$ & $2.52 \mathrm{~b}$ \\
Chester & $2.43 \mathrm{~b}$ & $194.46 \mathrm{~b}$ & $2.99 \mathrm{a}$ \\
Arphe & $4.03 \mathrm{a}$ & $260.26 \mathrm{a}$ & $2.42 \mathrm{~b}$ \\
Boata & $1.96 \mathrm{~b}$ & $92.36 \mathrm{c}$ & $2.31 \mathrm{~b}$ \\
\hline LSD 0.05 & 1.27 & 32.45 & 0.40 \\
\hline
\end{tabular}

Values shown in different letters in the same column are different at 0.05 (Duncan test)

Table 4

Plant characteristics of blackberry varieties (2018)

\begin{tabular}{lcccccc}
\hline Varieties & $\begin{array}{c}\text { Cane num- } \\
\text { ber }\end{array}$ & Cane length & $\begin{array}{c}\text { Cane dia- } \\
\text { meter }\end{array}$ & $\begin{array}{c}\text { Cluster number } \\
\text { per cane }\end{array}$ & $\begin{array}{c}\text { Fruit number per } \\
\text { cluster }\end{array}$ & Cane yield (g) \\
\hline Jumbo & $4.53 \mathrm{ab}$ & $260.56 \mathrm{~b}$ & $3.57 \mathrm{c}$ & $0.43 \mathrm{ab}$ & $13.62 \mathrm{a}$ & $14.07 \mathrm{a}$ \\
Chester & $3.80 \mathrm{~b}$ & $247.73 \mathrm{~b}$ & $4.26 \mathrm{a}$ & $0.60 \mathrm{a}$ & $9.76 \mathrm{ab}$ & $9.10 \mathrm{ab}$ \\
Arphe & $6.53 \mathrm{a}$ & $350.80 \mathrm{a}$ & $3.90 \mathrm{~b}$ & $0.13 \mathrm{~b}$ & $13.33 \mathrm{a}$ & $1.75 \mathrm{~b}$ \\
Boata & $2.53 \mathrm{~b}$ & $149.96 \mathrm{c}$ & $3.25 \mathrm{~d}$ & $0.06 \mathrm{~b}$ & $3.33 \mathrm{~b}$ & $1.01 \mathrm{~b}$ \\
\hline LSD 0.05 & 2.32 & 45.76 & 0.31 & 0.44 & 8.39 & 12.22 \\
\hline
\end{tabular}

Values shown in different letters in the same column are different at 0.05 (Duncan test)

Table 5

Fruit colors of blackberry varieties (2018)

\begin{tabular}{lccc}
\hline Varieties & $\mathrm{L}$ & $\mathrm{C}$ & $\mathrm{H}$ \\
\hline Jumbo & $14.94 \mathrm{a}$ & $5.64 \mathrm{~b}$ & $30.66 \mathrm{a}$ \\
Chester & $16.23 \mathrm{a}$ & $4.99 \mathrm{~b}$ & $28.13 \mathrm{a}$ \\
Arphe & $16.67 \mathrm{a}$ & $5.01 \mathrm{~b}$ & $27.61 \mathrm{a}$ \\
Boata & $16.65 \mathrm{a}$ & $11.53 \mathrm{a}$ & $20.26 \mathrm{a}$ \\
\hline LSD 0.05 & N.S. & 3.81 & N.S. \\
\hline
\end{tabular}

Values shown in different letters in the same column are different at 0.05 (Duncan test)

N.S.: Non-significant 
Altuntaş and Pirlak / Selcuk J Agr Food Sci, (2020) 34 (1), 1-6

Table 6

Pomological characteristics of blackberry varieties (2018)

\begin{tabular}{lcccccc}
\hline Varieties & Fruit shape & Fruit taste & Fruit aroma & Fruit width $(\mathrm{mm})$ & Fruit length $(\mathrm{mm})$ & Fruit weigth $(\mathrm{g})$ \\
\hline Jumbo & Long-conical & 3 & 3 & $17.39 \mathrm{a}$ & $18.45 \mathrm{a}$ & $3.60 \mathrm{a}$ \\
Chester & Short-conical & 3 & 4 & $17.47 \mathrm{a}$ & $15.69 \mathrm{a}$ & $2.81 \mathrm{a}$ \\
Arphe & Spherical & 4 & 5 & $12.25 \mathrm{ab}$ & $10.71 \mathrm{ab}$ & $1.19 \mathrm{~b}$ \\
Boata & Short-conical & 3 & 3 & $4.88 \mathrm{~b}$ & $5.07 \mathrm{~b}$ & $0.72 \mathrm{~b}$ \\
\hline LSD 0.05 & - & - & - & 7.92 & 8.15 & 1.27 \\
\hline
\end{tabular}

Values shown in different letters in the same column are different at 0.05 (Duncan test)

Table 7

Chemical characteristics of blackberry varieties (2018)

\begin{tabular}{lcccc}
\hline Varieties & TSS $(\%)$ & $\mathrm{pH}$ & Titrable acidity (\%) & Vitamin C (mg/100 g) \\
\hline Jumbo & $16.03 \mathrm{~b}$ & $3.71 \mathrm{c}$ & $0.60 \mathrm{a}$ & 26.39 \\
Chester & $14.20 \mathrm{c}$ & $3.57 \mathrm{~d}$ & $0.38 \mathrm{~b}$ & 26.67 \\
Arphe & $17.13 \mathrm{a}$ & $3.93 \mathrm{a}$ & $0.33 \mathrm{c}$ & 24.98 \\
Boata & $16.53 \mathrm{ab}$ & $3.90 \mathrm{~b}$ & $0.34 \mathrm{c}$ & 25.55 \\
\hline LSD 0.05 & 0.63 & 0.02 & 0.02 & Ö.D \\
\hline
\end{tabular}

Values shown in different letters in the same column are different at 0.05 (Duncan test)

N.S.: Non-significant

\section{References}

Ağaoğlu S, Çelik M, Atila S (2003). Bazı ahududu çeşitlerinin Ayaş (Ankara) koşullarına adaptasyonu üzerine ön değerlendirmeler, Ulusal Kivi ve Üzümsü Meyveler Sempozyumu, Bildiri Kitabı, 319324.

Ağaoğlu SY, Eyduran SP, Çelik M (2006). Bazı bögürtlen çeşitlerinin Ayaş (Ankara) koşullarına adaptasyonu üzerinde araştırmalar. II. Ulusal Üzümsü Meyveler Sempozyumu, Bildiri Kitabı, Tokat: 231-236s.

Akbulut M, Kaplan N, Macit İ, Özdemir C (2003). Samsun Çarşamba Ovası koşullarına uygun böğürtlen çeşitlerinin belirlenmesi. I. Ulusal Kivi ve Üzümsü Meyveler Sempozyumu Bildirileri, 357360.

Barut E (2004). Dünya ve Türkiye'de üzümsü meyve yetiştiriciliği ve ticareti, Türktarım Dergisi, 156, 60-67.

Cangi R, İslam A (2003). Bazı böğürtlen çeşitlerinin Ordu ekolojik koşullarına adaptasyonu üzerine araştırmalar (2000-2002 Gözlem Sonuçları), Ulusal Kivi ve Üzümsü Meyveler Sempozyumu Bildirileri, 348-352.

Çetiner M, Yalçın N, Ağar T (1993). Nessy" ve "Theodor Reimers" böğürtlen çeşitlerinin in vitro klonal çoğaltılması, Doğa Türk Tarım ve Ormancllık Dergisi, 55-64.

Esmek İ, Kızılcı G, Karadoğan B, Karadoğan NN (2011). Bazı bögürtlen (Rubus fructicosus L.) çeşitlerinin Erzincan yöresine adaptasyonu, Türkiye 6. Ulusal Bahçe Bitkileri Kongresi, 4-8 Ekim. Yayın No:2, Şanliurfa.

Gerçekçioğlu R, Özdemir Z, Güneş M, Edizer Y (2003). Bazı ahududu çeşitlerinin Tokat yöresine adaptasyonu [1999-2002 (4 Y1llık) Gözlem
Sonuçlar1], Ulusal Kivi ve Üzümsü Meyveler Sempozyumu, Bildiri Kitabı, 330-333.

Göktaş A, Demirtaş İ, Atasay A (2006). Bazı böğürtlen ve frenküzümü çeşitlerinin Eğirdir (Isparta) yöresine adaptasyonu. II, Ulusal Üzümsü Meyveler Seтроzуити, 151-156.

Hall H, Cohen D, Skirvin R (1986). The inheritance of thornlessness from tissue culture-derived 'Thornless Evergreen'blackberry, Euphytica, 35 (3), 891-898.

İslam A, Çelik H, Aydın E, Yıldız A (2009). Bazı böğürtlen çeşitlerinin Hayrat ekolojik koşullarına adaptasyonu, III Ulusal Üzümsü Meyveler Sempozyomu, Kahramanmaraş, 2009, 96-104.

Kaplan N, Onur C, Demirsoy L, Demirsoy H (1999). Karadeniz Bölgesinde frenküzümü, ahududu ve bögürtlen yetiştiriciliğinin önemi ve geleceğgi, Karadeniz Bölgesinde Üretim ve Pazarlama Sетровуити, 112-118.

Kurt H, Turan A, Ruşen M (2003). Bazı ahududu ve böğürtlen çeşitlerinin Giresun ekolojik koşullarına adaptasyonu (2000-2003 Sonuçları), Ulusal Kivi ve Üzümsü Meyveler Sempozyumu, Bildiri Kitabı, 365368.

Moore J (1984). Blackberry breeding [Rubus, subgenus Eubatus], HortScience, 19 (2), 183-185.

Onur C (1999). Bazı frenküzümü (Ribes spp.), ahududu ve böğürtlen (Rubus spp) çeşitlerinin evaluasyonu, Türkiye III. Ulusal Bahçe Bitkileri Kongresi, 772-775.

Pehluvan M, Güleryüz M (2004). Ahududu ve böğürtlenlerin insan sağlığı açısından önemi, Bahçe, 33 (1), 51-57.

Poling EB (1997). Blackberries, Journal of Small Fruit \& Viticulture, 4 (1-2), 33-69.

Pearson D (1976). The chemical analysis of foods 7 th ed. Churchill Livingstone: 6-14, 200-222. 